\title{
Anicónica, cruel y nómada: Lima la sublime*
}

\author{
Aniconic, cruel and nomadic: Lima The Sublime
}

\author{
Patricia Ciriani** \\ Universidad Nacional de Ingeniería \\ Recibido: 20 de agosto de 2020 \\ Aceptado: 23 de setiembre de 2020
}

\section{RESUMEN}

Más allá de lo bello y lo feo, y lejos de satisfacer el afán planificador del urbanismo moderno, Lima se afirma como un laboratorio social donde el ritmo hípermoderno dominante coexiste con experiencias premodernas. El concepto de lo sublime, que desarrolló Kant en una teoría estética ilustrada que buscaba emancipar al hombre de la naturaleza, ayuda a descentrar la mirada del esteta urbanita y reconocer en la aparente ilegibilidad de las representaciones sociales limeñas, el punto de partida para repensar la ciudad desde la multiplicidad cultural. La difusa identidad de Lima, que no tiene ni centro ni periferia delimitados, nos obliga a aplicarle criterios estéticos ajenos al urbanismo clásico: lo informe de Bataille y Krauss; el teatro de la crueldad de Artaud; la deriva de Debord; la meseta, el nomadismo y el cuerpo-sin-órganos de Deleuze y Guattari; la posmodernidad optimista de Maffesoli.

Palabras clave: Lima, arquitectura, imaginarios urbanos, descentramiento, multiplicidad cultural, deriva urbana.

\begin{abstract}
Beyond beauty and ugliness, and far from catering to modern urban planning's contingencies, Lima stands as a social laboratory where a dominant hypermodern rhythm coexists with premodern experiences. Kant's concept of the sublime, which he developed as an enlightened aesthetical theory aiming to emancipate man from nature, is essential in decentring an urbanite aesthete's perspective and recognizing in the apparent illegibility of Lima's social representations the starting point for rethinking city values as stemming from a cultural multiplicity. Lima's diffused identity, which lacks a properly defined city centre and outskirts, forces us to apply aesthetic views unknown to mainstream town planning: Bataille's and Krauss' formlessness; Artaud's theatre of cruelty; Debord's urban drifting; Deleuze's and Guattari's plateaus, nomadism and body without organs; Maffesoli's optimistic post-modernism.
\end{abstract}

Keywords: Lima, architecture, urban imaginaries, decentring, cultural multiplicity, urban drifting.

* Antecedentes del documento. Este texto forma parte de una investigación personal prevista de publicarse como libro bajo el título Lima la sublime. Una primera versión se presentó oralmente en la $1^{\text {a }}$ Noche de la Filosofía en la Casa de la Literatura, en abril de 2017 y en el III Congreso de Investigaciones en Arte y Diseño PUCP, en julio de 2017.

** Patricia Ciriani Espejo. Licenciatura y Maestría de historia del arte en la Sorbona (París 1). Licenciatura de Letras y Civilización angloamericanas (París 3). Posgrado de urbanismo en la Universidad Politécnica de Cataluña (Barcelona). 


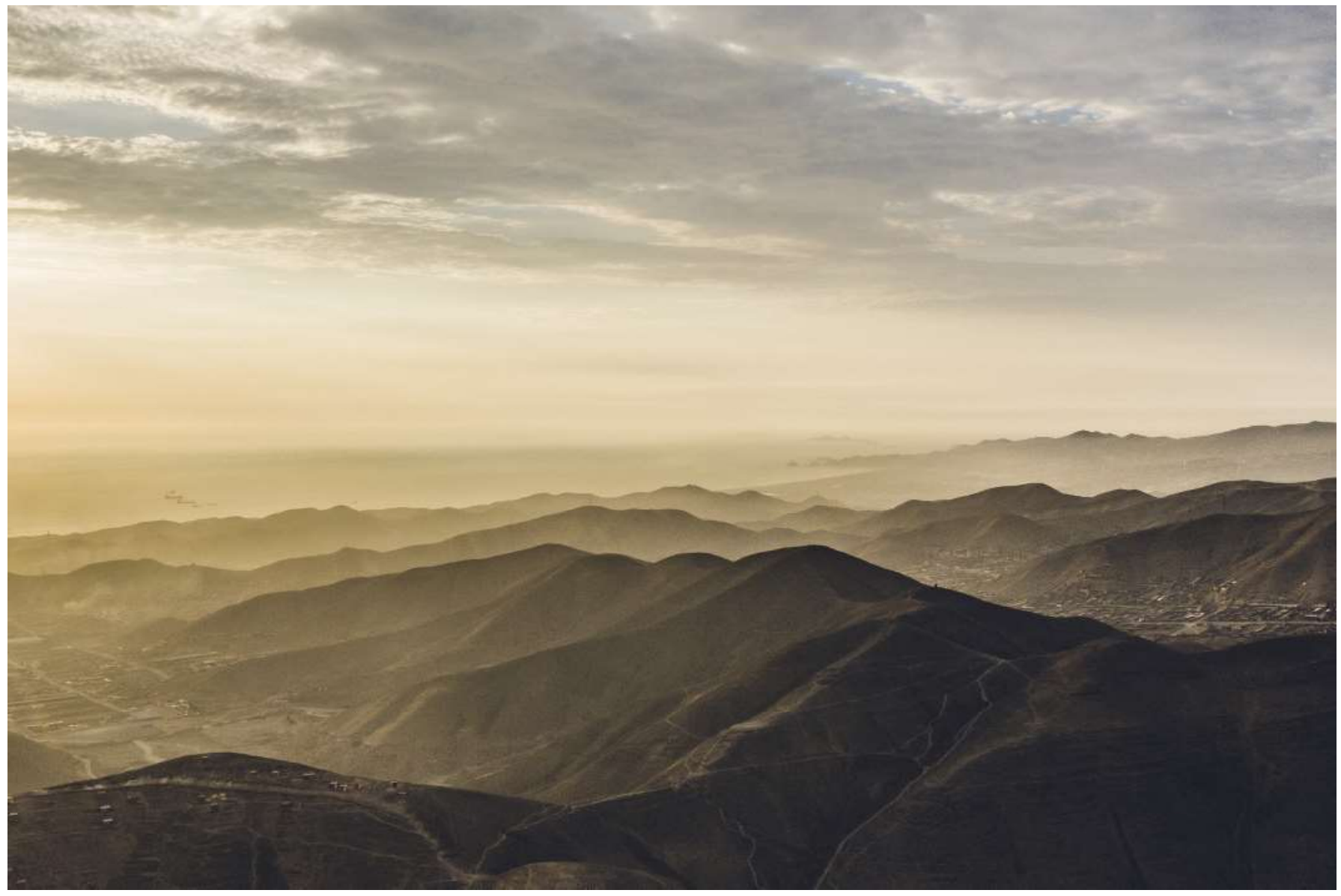

Mar y cerros. Ventanilla, Lima, 2019. Foto @ Eleazar Cuadros.

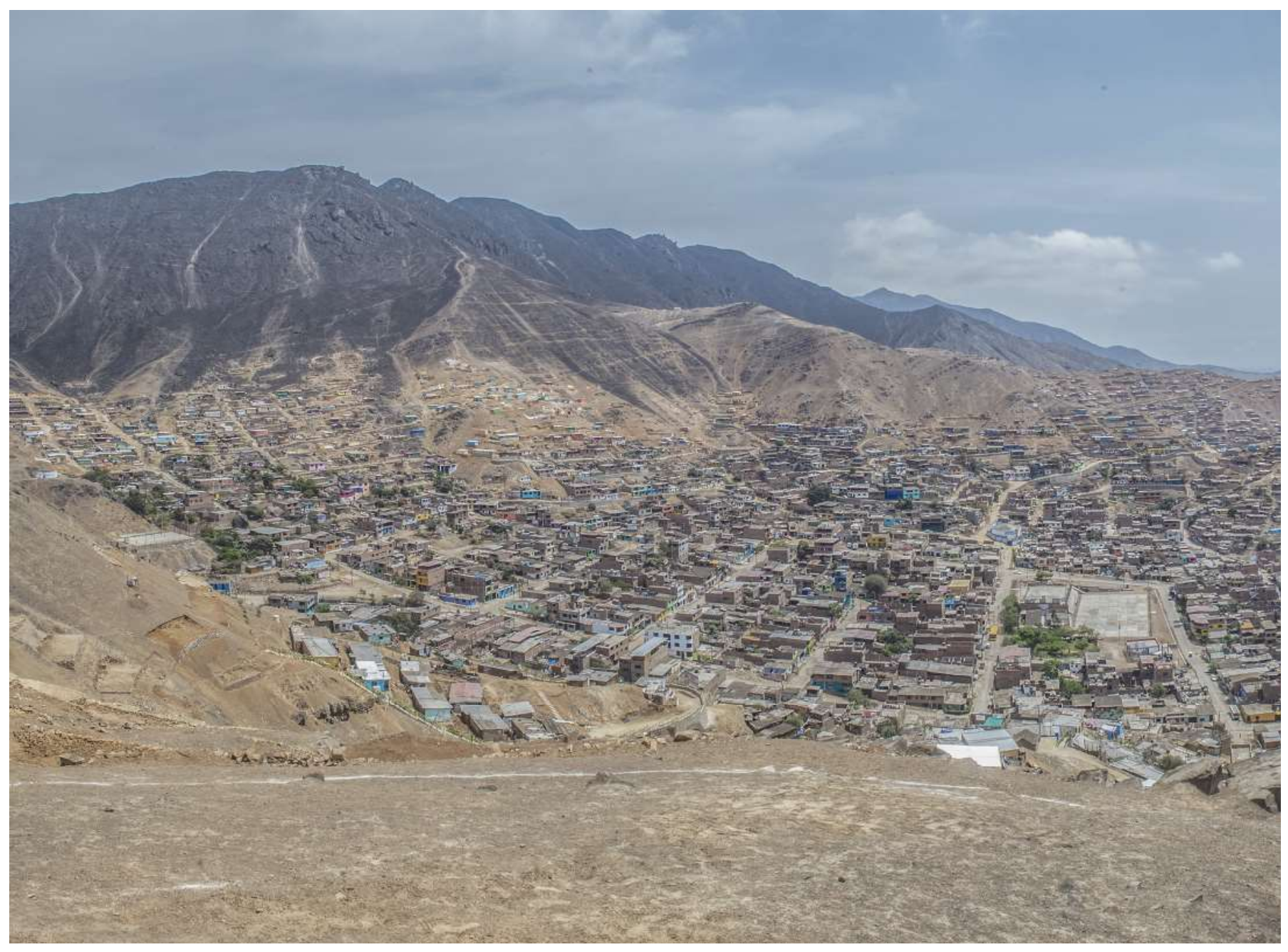




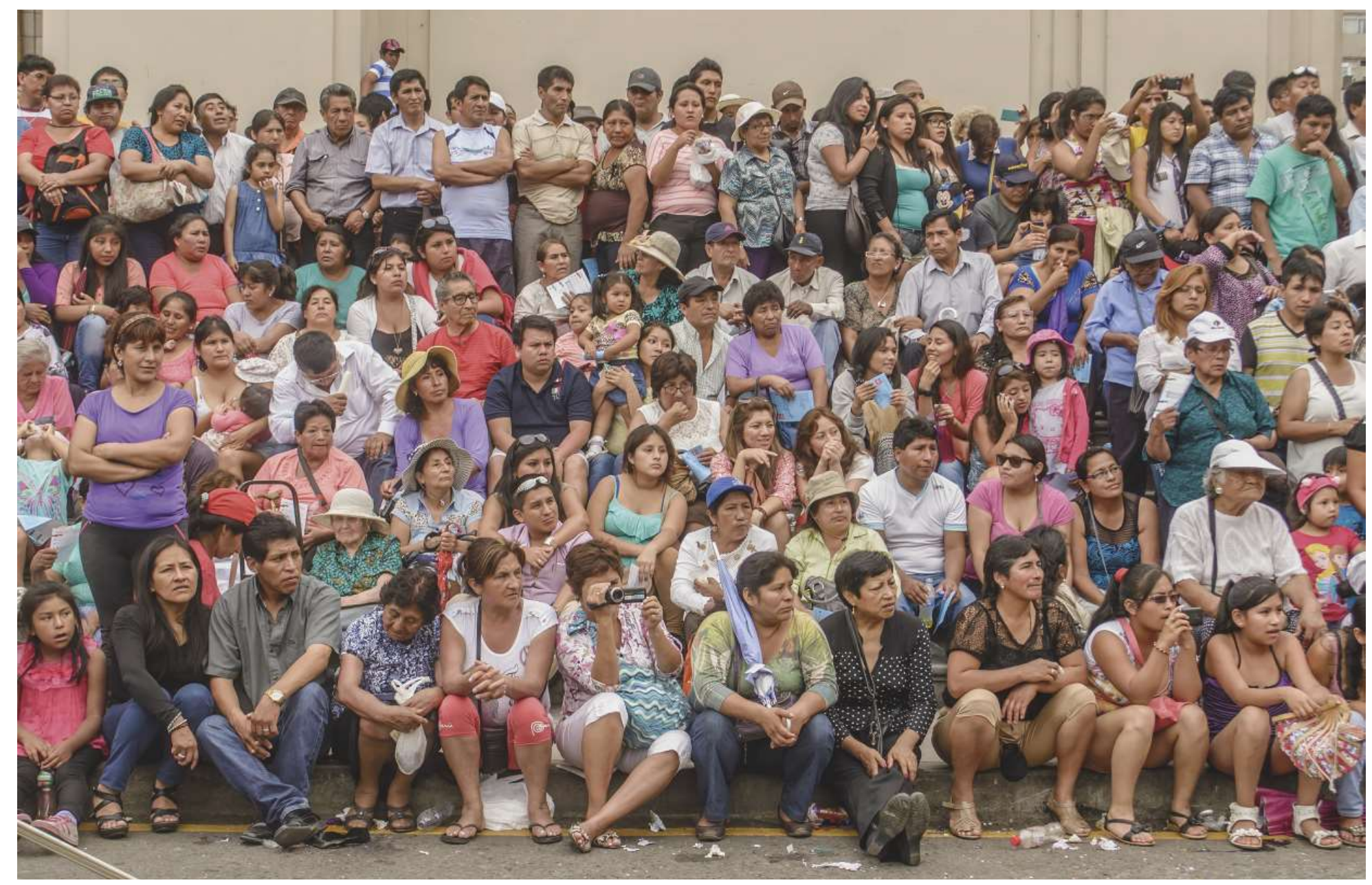

Tribuna limeña. Cercado, Lima. 2015. Foto @ Eleazar Cuadros.

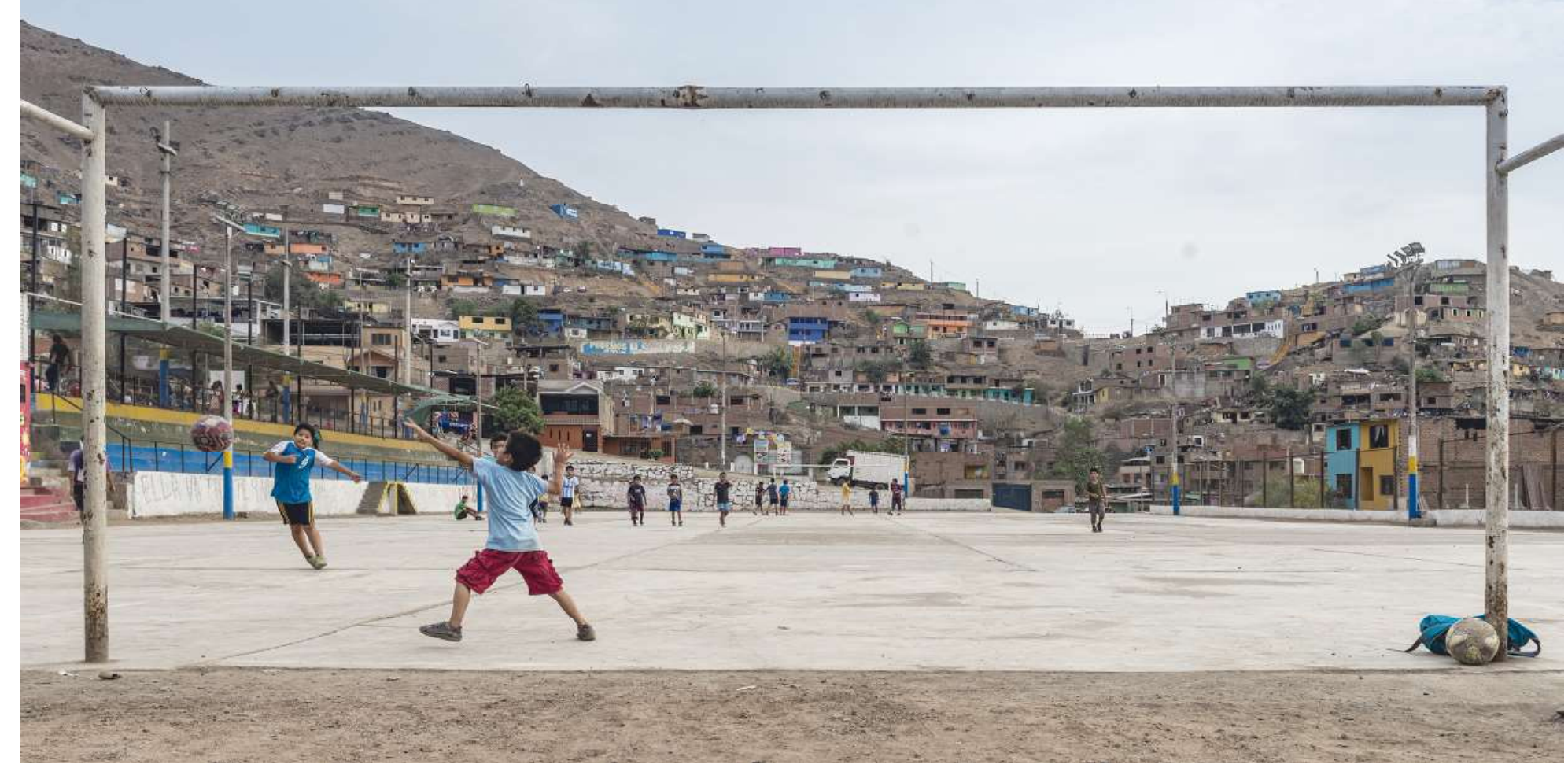




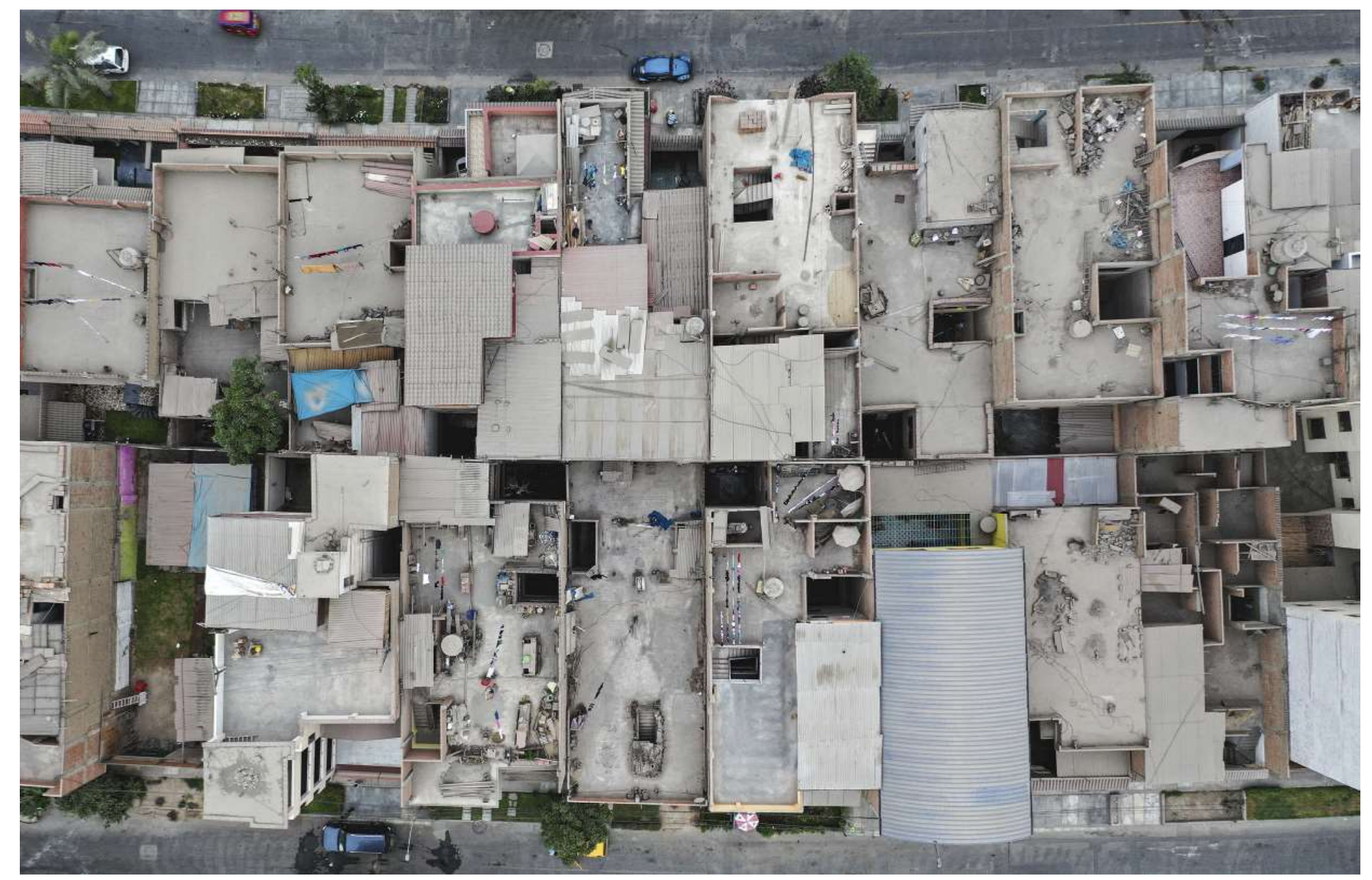

Manzanas de Pro. Los Olivos, Lima. 2018. Foto ® Eleazar Cuadros.

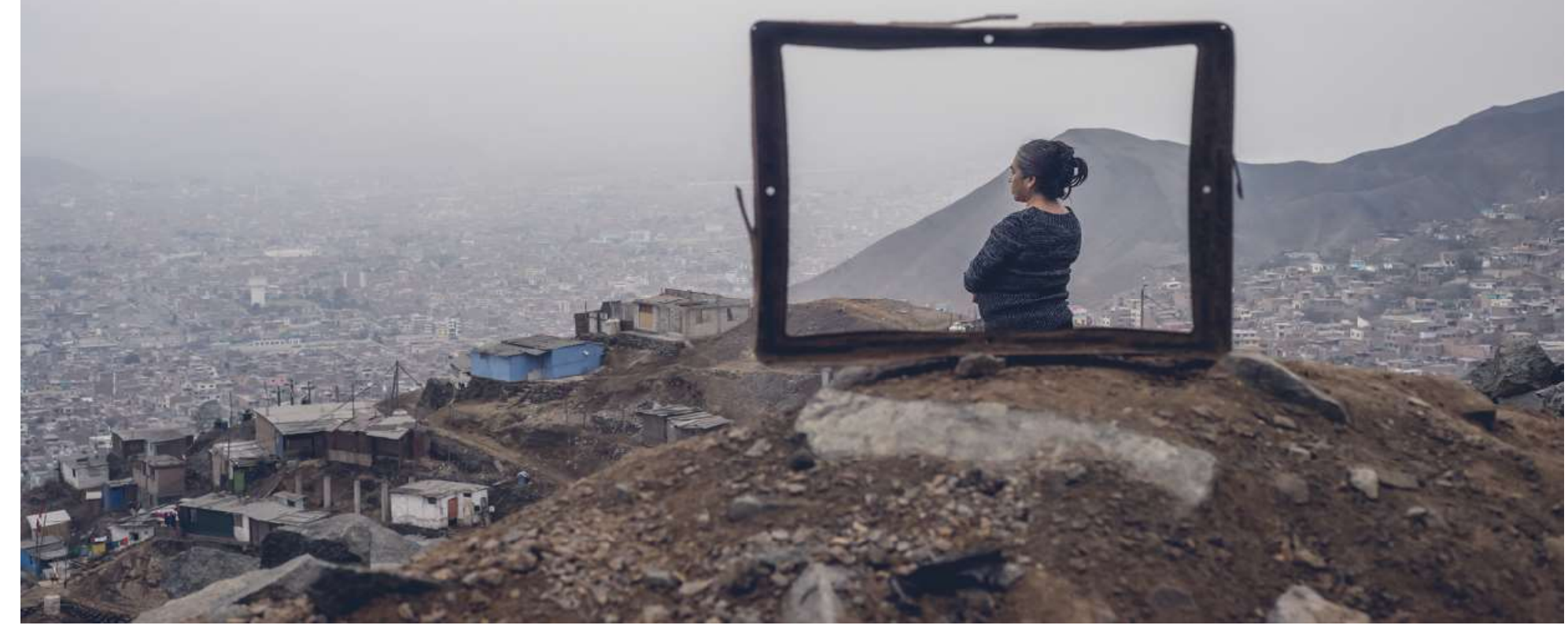




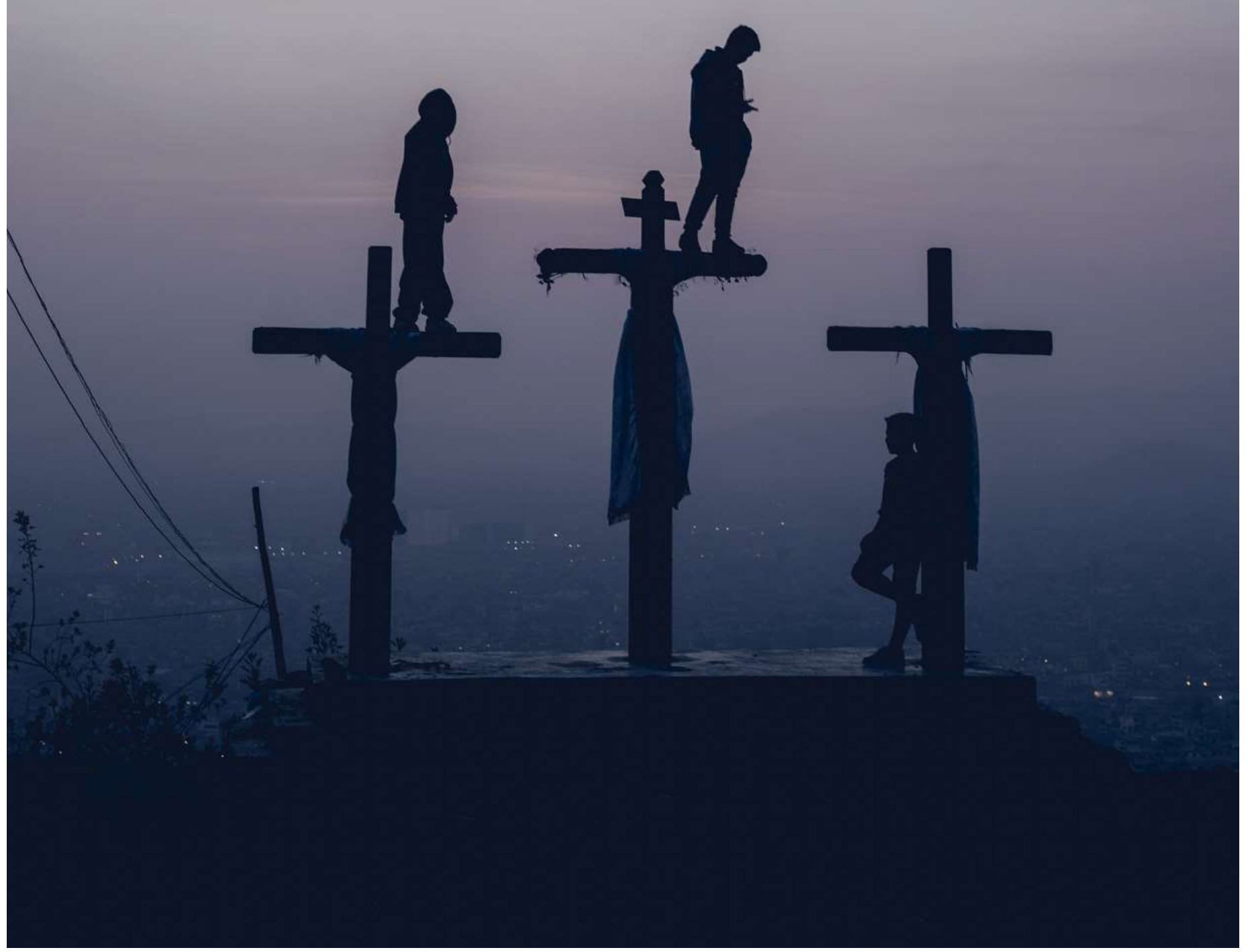




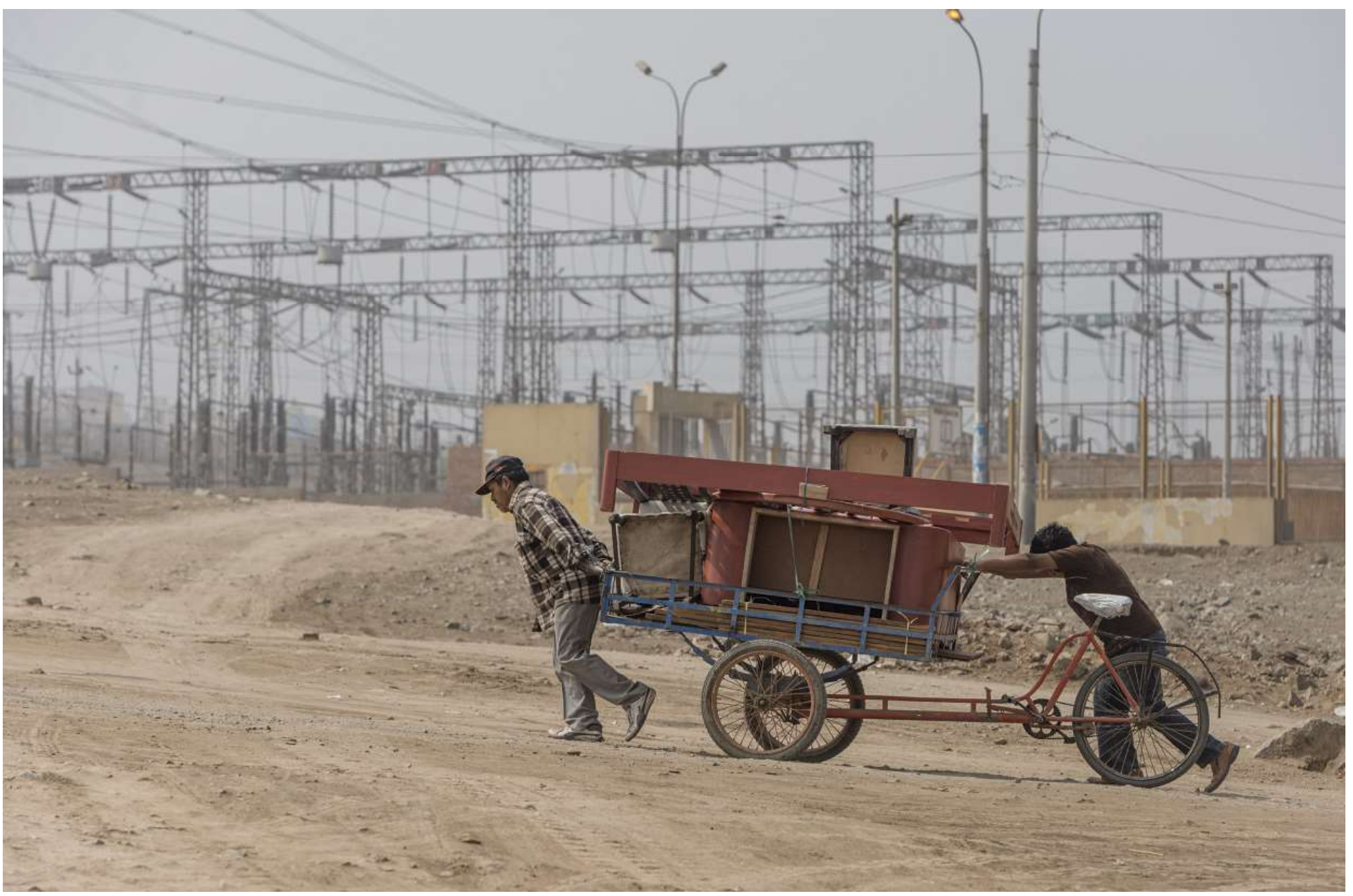

Triciclo Perú. Carabayllo, Lima. 2019. Foto @ Eleazar Cuadros.

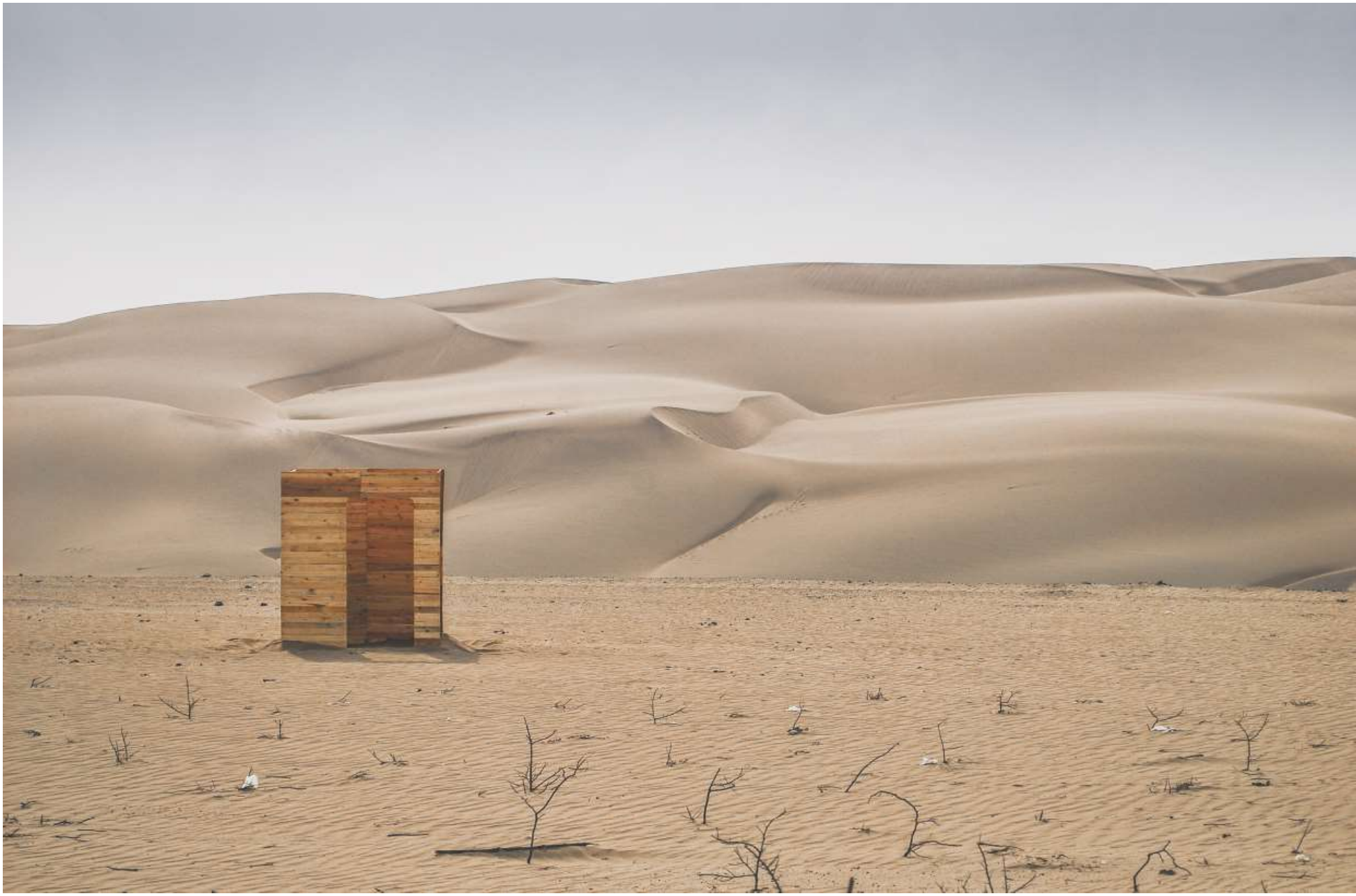



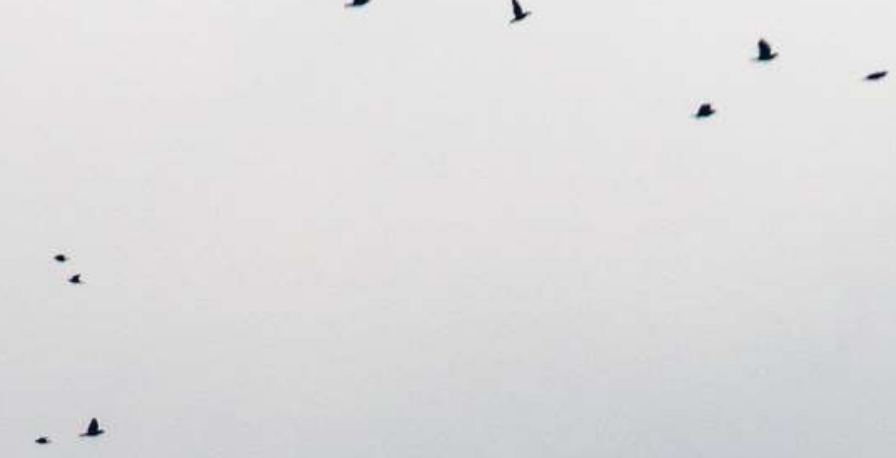

$-$

. 
Lo que llamamos posmoderno consiste, en parte, en retomar elementos premodernos que son utilizados y vividos de una manera diferente. (...) En ese sentido lo irreal (...) es el mejor medio para entender lo real, es decir lo que se da a vivir en la eflorescencia de lo trágico cotidiano.

Michel Maffesoli (1993, p. 23)

Hablar de Lima racionalmente es como un imposible. Hay una maldición en pensar, proyectar, planificar la capital peruana. Los urbanistas que lo hacen acaban derrotados en sus planes $^{1}$ y devueltos a la universidad sin agradecimiento. Esta sociedad parece impotente para actuar de forma coordinada, consciente, racional, objetiva, sobre una geografía tan potente con condiciones climáticas tan drásticas. La población queda a merced de desbordes de ríos, terremotos, maremotos.

Hay un contraste brutal entre estos desbordes recurrentes y la placidez habitual del clima, muy complaciente, de promedio veinte grados con pocas variaciones de temperatura y una humedad constante y sofocante. Nos pone a los humanos en la situación de peces inmersos en un océano, creando continuidad con el útero materno. Como nuevos nacidos que necesitan construir un caparazón porque nadie ha previsto que sean arrojados al mundo. He ahí la necesidad de este tribalismo tan premoderno como posmoderno que analiza el sociólogo francés Maffesoli.

Lima, la metrópoli de 10 millones de habitantes, 43 distritos, 15 kilómetros de costa pacífica, 365 huacas registradas, 4000 años de antigüedad y 10 años de boom inmobiliario... es una ciudad fragmentada en múltiples identidades. Pero Lima sobre todo es una ciudad sin rostro. Sin skyline reconocible. El cerro San Cristóbal con su cruz, el acantilado y el conjunto de torres de la avenida Canaval y Moreyra a duras penas consiguen estabilizar una imagen de la capital. La velocidad con la cual se destruye el patrimonio del siglo XX precipita el olvido de las memorias barriales. Queda una fisionomía magmática de baja altura, de cúbica volumetría multicolor, regada por el polvo color tierra-arena, marrón/ocre/gris.

Si se quisiera colocar Lima en el mapa de las ciudades de postal, le faltaría un ícono al cual corresponderse. Los turistas no la consideran bella pues más que ciudad eterna es la ciudad del presente absoluto, donde la realidad supera la ficción. Sin embargo, al nivel táctil, olfativo -y qué decir del gustativo-, Lima le gana a la mayoría de las capitales del mundo. La experiencia sonora de la ciudad es rica en mil anécdotas, si uno logra abstraerse del tráfico automovilístico. Lima es, pues, una fabulosa urbe de los sentidos. Lima y sus micro-climas es una cuna para estos "ojos de la piel" que invocaba el arquitecto finlandés Juhani Pallasmaa (1996). Activan nuestro apetito los ambulantes que traen comida casera a las esquinas, los afiladores y su timbre evocador de un mundo antiguo y a la vez cercano, mientras se va anestesiando nuestra memoria colectiva a medida que desaparecen las huacas prehispánicas, las calles abiertas, los parques gratuitos, las casonas eclécticas (y las modernas también), so pretexto de que no rentabilizan el suelo al ritmo de la hipermodernidad.

\section{Lima sublime}

Immanuel Kant analizó dos categorías de lo sublime. En primer lugar, lo sublime matemático: cosas absolutamente grandes, en comparación con las cuales todo el resto es pequeño. Nada de lo que vemos o imaginamos es estrictamente sublime, porque lo podemos imaginar pequeño en comparación con otra cosa. Pero a veces percibimos cosas que nuestra imaginación no puede considerar en su totalidad. Por ejemplo, los rascacielos: no podemos quedarnos lo suficientemente cerca ni lejos para poder representarlos completamente en la cabeza. Traen la idea de infinito. Poder pensar el infinito indica que tenemos una facultad no limitada a la sensación. Trasciende cualquier norma del sentido, la razón. Y eso procura placer. Pero pasa por el displacer de sentir que nuestra imaginación es incapaz de contener la totalidad.

En segundo lugar, lo sublime dinámico: la naturaleza vista como poderosa y terrible pero que no nos puede poner en peligro (por ejemplo, estar adentro de una casa observando una tormenta). Nos genera escalofrío y excitación. Pero es solo nuestra disposición mental que es sublime, no la naturaleza. En términos morales, continua Kant, cualquiera puede experimentar lo sublime porque todos tenemos principios morales. 
El sentimiento de lo sublime es, pues, un sentimiento de dolor que nace de la inadecuación de la imaginación, en la apreciación estética de las magnitudes, con la apreciación mediante la razón; y es, al mismo tiempo, un placer despertado, por la concordancia que tiene justamente ese juicio de inadecuación de la mayor facultad sensible con ideas de la razón, en cuanto el esfuerzo hacia éstas es para nosotros una ley (...). (Kant, 2011, p. 177)

¿Es infinita Lima? Ante todo, es una realidad estadística que Lima supera la capacidad humana de abarcarla tanto a pie como en auto. Del km. 50 de la Panamericana Norte, en el límite del distrito de Ancón con la provincia de Huaral, hasta el km. 70 de la Panamericana Sur, en el límite del distrito de Pucusana con la provincia de Cañete, Lima suma una extensión de poco más de $130 \mathrm{~km}$. de costa y playa. Hacia el este se extiende aproximadamente hasta el km. 50 de la Carretera Central, en el límite del distrito de Lurigancho-Chosica con la provincia de Huarochirí. La superficie de Lima se extiende hasta los $2672 \mathrm{~km}^{2}$, mientras Barcelona solo tiene 102 km²; París, 105 km²; Nueva York, 789 km²; Berlín, 892 km²; Los Ángeles, 1302 km²; Ciudad de México, 1485 km²; São Paulo, 1521 $\mathrm{km}^{2}$; Londres, $1572 \mathrm{~km}^{2}$; Tokio, $2188 \mathrm{~km}^{2}$. Solo China supera al Perú con Shanghai, $6340 \mathrm{~km}^{2}$, y Pekín, $16411 \mathrm{~km}^{2}$, entre otras capitales de provincia. Esa extensión vuelve indiscernible los confines de la ciudad, que se diluyen en un tejido muy poco denso de par en par.

Pero lo infinito no solo remite a los bordes de Lima, sino que está incrustado en el seno de un mismo barrio. En una deriva con alumnos $^{2}$, de Miraflores a Surco, nos vimos pasar de un tejido urbano globalizado de nuestra modernidad consumista -grandes edificios y rótulos de tiendas anunciando en avenidas- a un tejido complejo de escala doméstica, aunque de uso público, de callejones sin asfalto con bodegas informales de escala muy barrial. Sentimos que irrumpíamos de repente en unos ambientes casi privados donde desaparecían las rejas y las puertas se dejaban abiertas entre una vivienda y la otra mientras las parrillas se compartían al aire libre: una confianza propia de las márgenes periféricas de una ciudad, inesperada en el corazón de distritos más modernos. Esa cualidad de barriada de escala muy cercana genera como una sensación de miopía, perdiéndose la relación con el entorno más amplio del barrio, del distrito, de la ciudad. Ese pasaje directo, sin transición, entre escalas territoriales y modos de vivir antinómicos, genera una sensación de infinidad de posibilidades, análoga al goce vivido entre guerras por los surrealistas en sus errancias a través de las calles de París.

La cualidad del sentimiento de lo sublime es que es un sentimiento de dolor sobre el juicio estético en un objeto, el cual, sin embargo, al mismo tiempo es representado como conforme a fin, lo cual es posible, porque la propia incapacidad descubre la conciencia de una ilimitada facultad del mismo sujeto, y el espíritu puede juzgar estéticamente esta última sólo mediante aquélla. (Kant, 2011, p. 179)

Otro aspecto de lo sublime, esencialmente presente, conserva pues la idea de un impensable en el pensamiento, pero de otra manera, más bruta, menos elocuente. En este sublime, se convoca la materia misma, sujeta al terror, a la sospecha, al deseo. Ya no es cuestión de trascendencia, sino más bien de una interrogación inmanente sobre la materia por el sujeto sublime, que busca la profundidad en la superficie, lo infinito dentro de lo finito.

Mientras lo bello corresponde a una estética de la mesura, lo sublime corresponde a una estética de la desmesura, el desborde, la hybris. Aquel comportamiento pasional donde la razón queda opacada. Hybris, desmesura, desborde popular, son comportamientos opuestos a los favorecidos por la polis griega, constituida desde la razón y la palabra dialogante.

\section{Lima anicónica}

Lima es una ciudad que resiste a pesar del cambio de sus propios emblemas. La estatua de Pizarro, inaugurada en la Plaza Mayor en 1935, como parte de las celebraciones conmemorativas del cuarto centenario de la fundación española de la ciudad, a pesar de ser tan emblemática, o precisamente por ello, fue removida de su sitio. $Y$ a pesar de que unos arquitectos protestaron contra ese atentado a la identidad de la capital del virreinato, fundamentalmente no cambió nada. No hay que olvidar que una de las funciones de las estatuas y de los emblemas es federar, reunir, dar unidad a los diferentes elementos que están en una plaza, en una ciudad. 
Lima es pensada desde el barroco como un gran despliegue de plazas. Esto es claramente perceptible en la plaza San Martín, donde se desata, además, la vida bohemia de la noche que le da fuerza cosmopolita, convocando a todo el Perú y sus turistas. La plaza es de todos los limeños y de todos los peruanos. De la misma manera que uno no es parisino porque ha nacido en París; vivir en París es vivir en una ciudad que pertenece al mundo entero pues el mundo entero viene a visitarla y -otrora, cuando era asequible- instalarse en ella. Esa sensación emana también de la plaza San Martín. Es la Lima que todos pueden apropiarse, como ocurre en cada manifestación popular, al contrario de la Plaza de Armas que se enreja completamente ante la menor manifestación, donde el Palacio de Gobierno y la Catedral congelan cualquier actividad pasadas las nueve de la noche.

Sin embargo, la plaza San Martín suma identidades contradictorias. Conlleva rezagos del colonialismo cultural, con su color blanco, originalmente de cuarzo, la organización espacial, los arcos, el estilo afrancesado de sus fachadas y la estatua de San Martín, aquel extranjero considerado fundador de la república, ubicada en el centro. Con su Club Nacional aún cerrado en parte a las mujeres, sigue siendo potencialmente el centro de la Lima poscolonial, de los hacendados. De día, se mueven los activistas políticos, las manifestaciones, los comerciantes, los cambistas y el jirón de la Unión. De noche, se abre a una cultura menos oficial, aunque institucionalizada, que son las discotecas, los bares, los prostitutos, los ladrones y los locos.

En cambio, la vida en las laderas de Lima es precisamente aquello que no es visible de la ciudad, porque nadie la visibiliza. Aquello que no se muestra, no tiene representación, tal vez porque no tiene rasgos específicos. Podría ser Bogotá, Ciudad de México o cualquier ciudad de Sudamérica con cerros. Entonces surge la pregunta: ¿qué hace que sea peruana? No es fácil decirlo. Lo cierto es que las laderas han acogido a migrantes de todo el Perú, con sus culturas andinas y selváticas tan diferentes de las costeñas. La falta de identidad unitaria es lo que permite a todos apropiarse del espacio. En la plaza San Martín, uno se siente en una capital que está dia- logando con otras capitales del mundo, con herencia europea sumada a la herencia muy potente del Virreinato. Una herencia que buscó legitimarse en la República pero que no lo logró a pesar de sus intentos. En cambio, en la Lima de las laderas está la vida propia, la vida sin artificio, sin maquillaje, que no intenta ser otra cosa que lo que es. Un espacio de colores espontáneos, en contraste con la artificialidad de la Lima de la plaza San Martín.

Aquella ausencia de algo que defina a la Lima no visible podría llevarnos a pensar que es una Lima sin identidad. Pero es esa no-identidad la que permite que uno se pueda sentir cómodo porque siente que está en Lima -o en cualquier otra ciudad sudamericana-. Es decir, hay una Lima que durante un tiempo se representaba por su centro histórico, su Plaza Mayor y la plaza San Martín, con todos sus íconos, pero aquella identidad se ha ido perdiendo con la migración hasta convertirse en lo que es hoy: un híbrido. En el otro caso, la Lima de las laderas, se supone que es una parte de la ciudad habitada por gente que no pertenecía a la ciudad y que ha venido de fuera, ha migrado y ha creado esta nueva Lima. Una Lima sin identidad, que va camino a buscar su propia identidad. Como si fueran dos procesos inversos: el de una Lima que ha tenido y hasta cierto punto tiene todavía una identidad que se va desdibujando, y la Lima moderna, construida por generaciones de migrantes, la Lima que va forjándose una identidad. Esta Lima es una Lima en crudo, sin refinamientos. Es una Lima que no está ya solamente en la periferia. Puede estar incluso en el medio de la otra Lima, por ejemplo.

Desarrollada sin planificación, Lima no está bien delimitada, no tiene rostro discernible, podríamos decir que es una ciudad informe, según la definición de Rosalind Krauss e Yve-Alain Bois de lo Formless, a raíz de Bataille (Bois \& Krauss, 1999) o amorfa. Es decir, una ciudad que no tiene determinación. Y lo indeterminado es, de acuerdo a Hegel, lo que no puede ser definido porque no tiene una identidad. $Y$ lo que no tiene identidad es aquello que no forma parte de una totalidad que es la que le da sentido o significación. Aquello que está separado de la totalidad, aquello que está fragmentado, es aquello que no tiene determinación. Lima se ha de- 
sarrollado de una forma desordenada e irracional. $Y$ una ciudad irracional no se puede representar conceptualmente. Porque la representación implica que aquello que uno se está representando tenga inteligibilidad.

\section{Lima meseta}

Ahora bien, ¿Lima no es inteligible? ¿O no es inteligible dentro de la lógica clásica de Occidente y su régimen de representación, que conforma también un régimen específico de poder? Al opuesto de la distancia buscada por la modernidad para asimilar un objeto, Lima nos exige estar dentro, estar en medio, como en una meseta, porque sólo entonces se hace inteligible. Si se la mira desde fuera, Lima es un caos. Pero no se entra a Lima, se está en Lima. Antes de dejarse ver, Lima se respira. No dejamos de respirarla por todos los poros de una piel empapada por la neblina. Uno se siente apachurrado por la atmósfera de esta ciudad. La atmósfera se hace más espesa y sin darse cuenta una se siente penetrada por su nebulosa natural que no se confunde con el smog artificial. Un cielo blanco a punto de explotar, pero que nunca explota. Un tiempo congelado en el vapor denso y volátil.

En ese sentido, decir que Lima es sublime significa introducir un criterio de inteligibilidad para Lima. Subvirtiendo la noción kantiana de lo sublime, podemos ver en la situación caótica de Lima precisamente lo real inabarcable, la vida misma, fluctuante y desbordante, mientras que lo otro, aquella ciudad modélica europea (París, Venecia, Roma, según la visión de las élites) es una osificación, una fosilización, un cementerio de la vida. Foucault ya proponía repensar las estructuras de poder para entender lo que determina la racionalidad. Y el panóptico de las cárceles modelos del siglo XIX como la Penitenciaria de Lima (1856-60), nos sirve para observar las ciudades hoy en día. Mientras algunas ciudades son panópticos donde se encarcela a la gente dentro mismo de su cuerpo, otras como Lima abren brechas de libertad.

\section{Lima del presente absoluto}

Lo sublime traza una vía entre la presentación y la representación. Presentar (del latín praesentare) entiende a la vez la idea de pre- sente y de presencia. Presentar es concretar la presencia de una cosa en el momento en que se manifiesta. Representación, al contrario, convoca siempre indirectamente la cosa, mediante una palabra o una imagen. Sustituye a la ausencia de la cosa una imagen que la colma y la redefine.

En las artes plásticas (pintura, escultura, grabado, arquitectura) está la historia contada por Plinio el Viejo sobre Callirrhoé, hija de Butades, que habría creado el primer retrato trazando el perfil de su amante partiendo para la guerra. El padre haría la primera escultura de relieve con arcilla y yeso. Ese mito hace del signo, un índice y un ícono a la vez. Otra representación mítica es el santo Sudario, a la vez trazo y reliquia, que procede de la desaparición progresiva -la descomposición- de la presentación, asegurándole su duración y ubicuidad. Así, el precio a pagar por la representación es la muerte. La imagen es la presencia de una ausencia.

La representación es, pues, el calco de una presentación inicial cuya alma y cuyo secreto conserva: siempre ese misterio de la presencia, que consagra el aura. Sin representación no hay visibilidad de la muerte. Quedamos en la pura presencia, el eterno inicio (arquè, principio fundador). Lima, al no tener un ícono que la represente, es la ciudad de la presencia absoluta.

\section{Callejones de la crueldad de reja proliferante}

Pero existe también una dimensión sublime de la Oscuridad y el Mal, contra lo sublime de la Luz y el Bien.

El teatro sólo podrá ser nuevamente el mismo, ser un medio de auténtica ilusión, cuando proporcione al espectador verdaderos precipitados de sueños, donde su gusto por el crimen, sus obsesiones eróticas, su salvajismo, sus quimeras, su sentido utópico de la vida y de las cosas y hasta su canibalismo desborden en un plano no fingido e ilusorio, sino interior. En otros términos, el teatro debe perseguir por todos los medios un replanteo, no sólo de todos los aspectos del mundo objetivo y descriptivo externo, sino también del mundo interno, es decir del hombre considerado metafísicamente. Solo así, nos parece, podrá hablarse otra vez en el teatro de los derechos de la imaginación. Nada significan el humor, 
la poesía, la imaginación si por medio de una destrucción anárquica generadora de una prodigiosa emancipación de formas que constituirán todo el espectáculo, no alcanzan a replantear orgánicamente al hombre, con sus ideas acerca de la realidad y su ubicación poética en la realidad. (Artaud, 1986, p. 104)

Con el dramaturgo francés Antonin Artaud podemos establecer una nueva ventana a través de la cual mirar una tempestad cotidiana: la televisión como escenario apocalíptico. Agresiones elevadas al rango de tragedias familiares, vecinales, cada día reanudadas, cada día nuevas y eficaces barreras virtuales entre las personas y su entorno, en un mundo reificado por las imágenes, como lo sentenciaba Guy Debord en su Sociedad del espectáculo (2000), publicada en 1967.

El teatro de la crueldad es cotidiano en la calle, donde luchan fuerzas antagónicas. Lima maltrata porque uno tiene que plegarse a ella, a su autoridad sin autores. No hay consenso sobre lo común, menos entonces sobre lo bello, que, como nos explica Immanuel Kant, es universalmente entendible sin concepto. En teoría, según Kant, no se teoriza lo bello, se aprecia entre todos por consensuo mutuo. Pues aquí en Lima esa visión común no existe, hay un divorcio entre las élites formadas en universidades, que favorecen el continuum de blanco-beige-marrón-gris, y el resto de la gente, colorinche y bulliciosa.

Contra la ambición del concepto (¿quién no hace conceptos hoy en día?), ambición paranoica de la voluntad de saber, volver a lo que Heidegger llamaba 'la indicación formal'. La indicación muestra. $Y$ aquel a quien se le muestra debe ver por sí mismo. Lo que remite a la necesidad de la experiencia viva, al aspecto prospectivo y progresivo del aprendizaje.

Esto es el relativismo intelectual. Relativización de los conceptos y puesta en relación de los pensamientos. Saber vivir y saber decir van a la par. Y como señalaba Kierkegaard: "en lo que respecta a los conceptos existenciales, el deseo de evitar las definiciones es una prueba de tacto". Cuánta elegancia de pensamiento en esta tierna aproximación que rompe con la brutalidad doctrinal de los nuevos inquisidores. Estos últimos "funcionan", como autómatas, a partir de un pensamiento disociado. Ciertamente, no es la primera vez que hay un alejamiento entre aquellos que "dicen" y aquellos que viven la realidad. Pero el alejamiento se convirtió, en nuestros días, en una fosa infranqueable. De ahí la necesidad de saber decir lo que se vive. Tal como decía Nietzsche: "los originales fueron aquellos que ponen los nombres". Con lo que recuerda que no hay original fuera de lo que es originario. (Maffesoli, 2009, p. 9)

\section{Lima nómada}

Hay un saber-hacer espontáneo en el manejo de los colores que parece asegurarnos que sí, el sentido común es el más común del mundo (expresión de la llustración que tantos Auschwitz han quebrado): el color tiene sus leyes y en Lima la gente sabe manejarlas. Colores complementarios, tonos vivos para levantar el espíritu: el color es el lujo del pobre. Los lomos de las casas se pintan de otro color, jugando con las dimensiones a la manera de De Stijl.

Necesitamos contradecir a Winckelmann. Para seguir creyendo que el summum de lo bello es lo clásico, y lo clásico es esculturalmente proporcionado, aunque cromáticamente chirriante. Para dejar de creer que el summum de lo bello es lo clásico, para afirmar que la pureza nunca existió, que nunca hubo clasicismo sino, veintiún siglos después, la invención de una arquitectura supuestamente racional, buscando los orígenes puros del arte de edificar. Ledoux en realidad propició con sus columnas de la Saline d'Arc-et-Senans un eclecticismo que abre la puerta al siglo XIX y sus reapropiaciones pompier.

New Babylon no se detiene en ninguna parte (porque la tierra es redonda); no conoce fronteras (porque ya no hay economías nacionales), ni colectividades (porque la humanidad es fluctuante). Cualquier lugar es accesible a cada uno y a todos. Todo el planeta se convierte en la casa de los habitantes de la tierra. Cada cual cambia de lugar cuando lo desea. La vida es un viaje sin fin a través de un mundo que se transforma con tanta rapidez que cada vez parece diferente. (Constant, 1996, p. 158)

Francesco Careri y el Colectivo Stalker en Roma reactivaron en la década de 1990 la deriva situacionista como método de aprendizaje, de conocimiento, de juego serio. Constant, con Aldo van Eyck en Ámsterdam y los Situacionistas en París, habían bebido del Homo ludens de Johan Hui- 
zinga (1938). Sin miedo no hay aprendizaje y en Lima hay mucho miedo, por eso sus habitantes son muy curtidos en experiencia y mucho más sabrosa resulta su relación humana, más vinculada a cosas reales, viscerales. Las necesidades del transeúnte son muy básicas: comer, beber, tener algo, aunque sea poco y siempre incompleto -el televisor plasma sobre piso de tierra, como se observa en casas de las laderas por el distrito más poblado de Lima, San Juan de Lurigancho-. No se siente la presión callejera del bullying, agresiones gratuitas, como en Francia (en sus grandes ciudades y periferias), sino hurtos o asaltos puntuales debidos a la necesidad.

La ciudad se construye a medida de los pasos, muchas calles son laberínticas como en la utópica New Babylon de Constant. Por lo tanto, la ciudad se presta a la deriva. De hecho, hasta hace siete años era invisible para las cámaras de Google y ahora sigue sin planificarse. En ausencia de programa de sociedad y de ciudad, nuestros pasos se vuelven programáticos.

En efecto, la acción de andar tiene una capacidad propositiva implícita: por un lado, como herramienta útil para cuestionar, replantear y partir de cero; por otro, como herramienta de producción de espacio público, generando intercambio, creando colectividad y procesos participativos. En definitiva, pone de manifiesto la utilidad de la deriva, en tanto acto de caminar de forma indeterminada, para articular aquel proyecto indeterminado.

Con ello deja entrever su verdadera contribución, asumiendo su aplicabilidad. Si proyectar es una manera de interpretar y transformar el mundo, no es menos cierto que caminar es un modo de comprender la realidad y ambas están estrechamente relacionadas. Es necesario caminar para proyectar, conocer para actuar.

\section{Lima, ciudad-sin-órganos}

Porque la realidad está por terminar, aún no está construida. De su consumación dependerá en el mundo de la vida eterna el retorno de una eterna salud.

Antonin Artaud (1977, p. 106)

Lima es difusa, pero eso no es necesariamente peyorativo. El urban sprawl que tanto se le critica, con el apoyo de la neblina, hace de Lima una ciudad miope, del aquí y ahora, que tiene su representación en la cultura quechua con la extraordinaria palabra quechua kay que une la locución disociada en latín de hic et nunc. En Lima son las personas las que generan lo urbano, como tantos eke$\operatorname{kos}^{3}$ modernos en forma de negocios ambulantes caseros.

Al contrario de la plaza San Martín donde los políticos y comercios están intentando, y han logrado en parte, impedir la perpetuación de una contra-cultura, el lugar donde las instancias de poder no pueden actuar tan fácilmente es en las laderas de Lima. Esas culturas alternativas al poder centralista de Lima capital parecen inasimilables por ser muy plurales y provenir de tantas culturas y geografías peruanas a la vez. Su fuerza resulta que es más difícil atacarlas, porque quienes las hacen y viven en ellas no están localizados, están aquí y allá, prenden luces sin avisar, en puntos dispersos, como luciérnagas. Claro, las luciérnagas se pueden extinguir, pero siempre vuelven a surgir. Es como si hubiera un pulso más vibrante, aunque menos coordinado que en la plaza San Martín. Estas zonas ubicadas en las laderas parecen aún estar a salvo del panóptico. El Agustino, por ejemplo, es un distrito en pleno corazón de la ciudad que sigue resistiendo al ordenamiento.

Entretanto, el cerro San Cristóbal se define ahora por sus entradas y subidas. Desde el terrible accidente de 2017, donde murieron varias personas que encima fueron robadas, ya no suben ni buses ni taxistas porque llegado a un punto la policía avisa que no se puede continuar. Es decir, estás en un lugar donde no tienes derechos -en pleno centro de Lima-, en un lugar que hasta hace poco era uno de los puntos focales del turismo. De un día para el otro, así como sacaron a Pizarro de la Plaza de Armas, sacaron del mapa de Lima al cerro San Cristóbal, uno de los pocos íconos que tiene la capital.

Por otro lado, las laderas tienen el Perú adentro de Lima. Se puede hacer trekking por las lomas en un viaje de aventura y de escalada. Aunque parezca extraño, uno puede encontrarse arriba de un cerro con el mismo 
ambulante que vende botellas de agua y pan caliente, con la bodega de cualquier barrio, con las mismas cosas que se come en cualquier parte de Lima. Presenciamos a la vez una homogeneidad de los insumos y una fuerte heterogeneidad de la geografía. Estamos acogidos en un continuo de la boca hasta la cima del cerro y nuestra mirada, nuestras sensaciones, nuestra libido arquitectónica, urbanística, están activadas al cien mil por ciento, porque se puede encontrar todo lo que se desee sin siquiera saber cómo. $Y$ de pronto tenemos unas vistas que uno no se espera tener y vivimos una pluralidad inesperada. Todo el país está en cada sitio. Lima es una sinécdoque, la parte por el todo, y una metonimia. En cualquier parte de Lima está todo Lima.

Esta idea de que en cualquier parte de Lima, de esta Lima de las laderas, está todo, contraviene, entre otras cosas, un principio canónico de Occidente según el cual el todo es más que la suma de las partes y del cual se deduce que la parte jamás puede contener al todo y que, por el contrario, sólo tiene sentido en función de él. Lo que pasa es que cada casa está vinculada con otras casas. No hay una vivienda que esté sola. Y se han construido en función de dónde está el tanque de agua, por dónde va a venir el cable de la electricidad: están pensadas todas juntas, en realidad. Quizás la cuestión de la organicidad no está planteada de la misma manera que un cuerpo. Es más la idea de un cuerpo-sin-órganos, como sugerían Deleuze y Guattari (1980). Es decir, hay una cosa que uno puede sacar de sí y darlo a otros, como en el caso de una escultura de Rodin, donde se puede sacar un brazo y colocarlo en otra escultura. Como una prótesis, que ya no es prótesis. El sufijo se vuelve prefijo o raíz, indiferentemente, ya no hay ni raíz ni sufijo ni prefijo y las cosas se transmutan, permutan de ser raíz a ser sufijo, a ser añadido, adjunto, coadyuvante. En cualquier momento uno toma un trozo de montaña y genera una micro-centralidad, una cancha de fútbol que es una centralidad posible pues reúne a la gente, a modo de plaza. Solo que no es pensada como las plazas europeas donde hay un intercambio de negocios posibles. Solo quedan ahí actividades específicas: el fútbol, una fiesta, una eventual manifestación. Pero no se atraviesa la plaza para ir a su casa, que es lo que pasaría en Europa. En Lima hay ciertos circuitos por los que uno pasa para hacer los quehaceres del día pero si uno va a la plaza, se expone.

Si reconocemos que Lima no ha conocido la modernidad en su globalidad urbana y vive en plena postmodernidad publicitaria, la tentación de seguir el entusiasmo de los Venturi \& Scott-Brown (2000) en su Learning from Las Vegas de 1972 es fuerte, para aceptar la situación con pragmatismo. Hacer cambios quirúrgicos, pero fundamentalmente acoger el caos urbano como el futuro orgánico de cualquier metrópolis. Semejante fatalismo se leía en la teoría de la "ciudad genérica" de Rem Koolhaas (2006), escrita en la década de 1990. Sin tomar posición, anunciaba que la partida ya estaba jugada: el crecimiento explosivo de las megalópolis impedía cualquier plan de rescate, y menos arquitectónico. Koolhaas nos invitaba más bien, con el cinismo más fructífero del planeta, a vivir la ciudad en su organicidad propia. Como es de notar en ambos planteamientos, se sugiere que la población debía resignarse al destino indicado por las corporaciones transnacionales o a las consecuencias que traían las relaciones económicas en condiciones de desigualdad, exclusión y segregación inmobiliaria.

¿Qué pueden hacer las autoridades para superar esta realidad pre-apocalíptica? Y ¿qué puede hacer el arte para activar consciencias, hoy entregadas al abandono y la indiferencia? Consideramos que la idea de la recuperación de la ciudad mediante el arte no responde a un capricho pues en el siglo XXI el arte, también, representa una vía y un poder para el cambio, para la transformación estética de la materia bajo pensamientos, gestos y formas, muchas veces afincados en la tradición, en el mundo de lo mágico o ritual. En ese sentido, el arte puede ser un camino para generar un sentido de comunidad participativa donde más hace falta.

El Proyecto Rímac es un buen ejemplo. Es una obra múltiple que abrió un camino inédito hacia un land art peruano, no solo involucrado en la defensa del medioambiente, sino que tuvo implicaciones científicas, revelando al pú- 
blico una fuente desconocida del río Rímac ${ }^{4}$. Es el tipo de obras que nos hace ver el paisaje de Lima, de mar a montaña, como un terreno fértil y abierto a la experimentación, y al artista como un agente heroico de transformación.

Cuando la arquitectura no se contextualiza más, en ciudades vueltas tan genéricas como los medicamentos, el arte -entre otros elementos de la cultura, como la comida o el deporte- queda como único amparo para no perder completamente la noción de lugar y hábitat, para colmar las brechas del espacio público. Un arte irrumpiendo, penetrando el espacio sin pedir permiso. Del graffiti de Bansky sobre el Muro de Gaza a las manifestaciones del colectivo No a Keiko ${ }^{5}$ en las elecciones peruanas de 2016, el arte visual como la performance artística siguen demostrando su capacidad para despertar consciencias con recursos mínimos. A mitad de camino entre un arte de escaparate, meramente formalista y una performance efímera que deja huérfanos a la masa de público de las calles: sí podemos devolver el potencial maravilloso a las ciudades sin dejar de ser críticos con el orden establecido.

\section{Notas}

1 El último Plan Metropolitano de Desarrollo Urbano de Lima y Callao (PLAM) quedó archivado apenas fue expuesto al público, en diciembre del 2014, cuando volvió en función el alcalde Luis Castañeda.

2 En el curso de Estética, Maestría en ciencias de Arquitectura - Historia, Teoría y Crítica de la Facultad de Arquitectura, Urbanismo y Artes de la Universidad Nacional de Ingeniería, en 2016.

\section{Referencias bibliográficas}

Artaud, A. (1977 [1947]). Van Gogh: el suicidado de la sociedad y Para acabar de una vez con el juicio de Dios. Fundamentos.

Artaud, A. (1986 [1938]). El teatro y su doble. Edhasa.

Bois, Y.-A. \& Krauss, R. (1999). L'Informe, mode d'emploi. Centre Pompidou.

Constant (1996). New Babylon. Una ciudad nómada. En L. Andreotti \& X. Costa (ed.), Teoría de la deriva y otros textos situacionistas sobre la ciudad. MACBA, Actar.

Debord, G (2000 [1967]). La sociedad del espectáculo. Pre-Textos.

Deleuze, G. \& Guattari, F. (2002 [1980]). Capitalismo y esquizofrenia, t. II. Mil mesetas. Pre-Textos.
La ciudad de Lima, asimismo, queda como escenario de un espectáculo permanente sin polaridad ni contenido. Lo que podemos esperar de un sistema informal como el peruano, sería que deje las mismas libertades al sistema artístico -aún no constituido como gremio ni como red institucional- que a la macro-economía. El reto consiste, en Lima como en París, que lanzó internacionalmente la Noche en Blanco, en abrir el espacio al público, crear costumbres de mezclar gentes y crear nuevos públicos para el arte y el disfrute común de la cultura contemporánea.

Pero si el arte es lo que marca, genera, define la identidad de una comunidad, ¿cómo entender que se importe sus modelos museísticos de un continente al otro? Existe el riesgo de transformar estas ciudades o barrios en parques temáticos de franquicia o bien en museos intangibles, como París y Barcelona, que controlan todo, desde el color de sus edificios y mobiliario urbano, hasta el contenido de los espectáculos por las Ramblas. En eso Lima ofrece un futuro interesante, si logra frenar la avalancha publicitaria y su mala interpretación de modelos culturales ajenos.

3 Un ekeko es la personificación del dios popular de la prosperidad, en forma de hombre lleno de objetos y billetes.

4 Autores del proyecto: Alejandro Jaime, Jorge Luís Baca de las Casas y Guillermo Palacios (http://rimac.wordpress. com). El río Rímac tendría dos fuentes de deshielo: el nevado Rajuntay, además del nevado Uco, como se suponía.

5 Keiko Fujimori es la hija del ex dictador Alberto Fujimori y lideresa del partido político Fuerza Popular que tomó la posta del padre cuando entró en la cárcel, en 2007.

Huizinga, J. (1972 [1938]). Homo ludens. Alianza.

Kant, I. (2011). Crítica del juicio. Técnos.

Koolhaas, R. (2006 [1995]). La ciudad genérica. Gustavo Gili Mínima.

Maffesoli, M. (1993). La contemplation du monde. Grasset.

Maffesoli, M. (2009). El reencantamiento del mundo. Una ética para nuestro tiempo. Dedalus.

Pallasmaa, J. (2014 [1996]). Los ojos de la piel. La arquitectura y los sentidos. Gustavo Gili.

Venturi, R.; Izenour, S.; Scott Brown, D. (2000 [1972]). Aprendiendo de Las Vegas. El simbolismo olvidado de la forma arquitectónica. GG Reprints. 


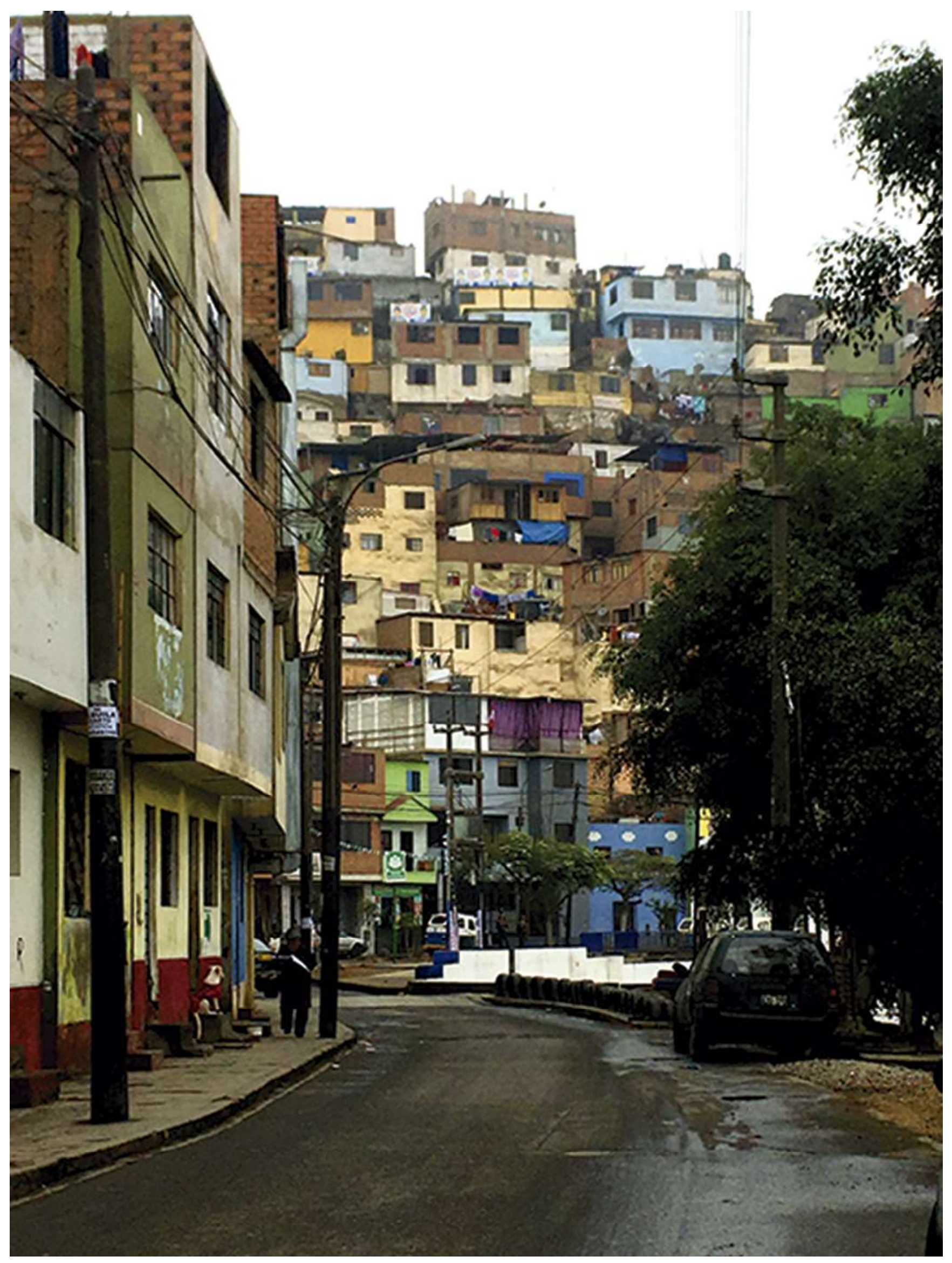

Rímac, 2018. Foto $\odot$ Manuel Serpa. De la serie Patrimonio berrinchudo limeño 


\section{ARQUITEXTOS}

ISSN 1819-2939 / ISSNe 2706-8099

Año 27, № 35, enero-diciembre de 2020, 49-66

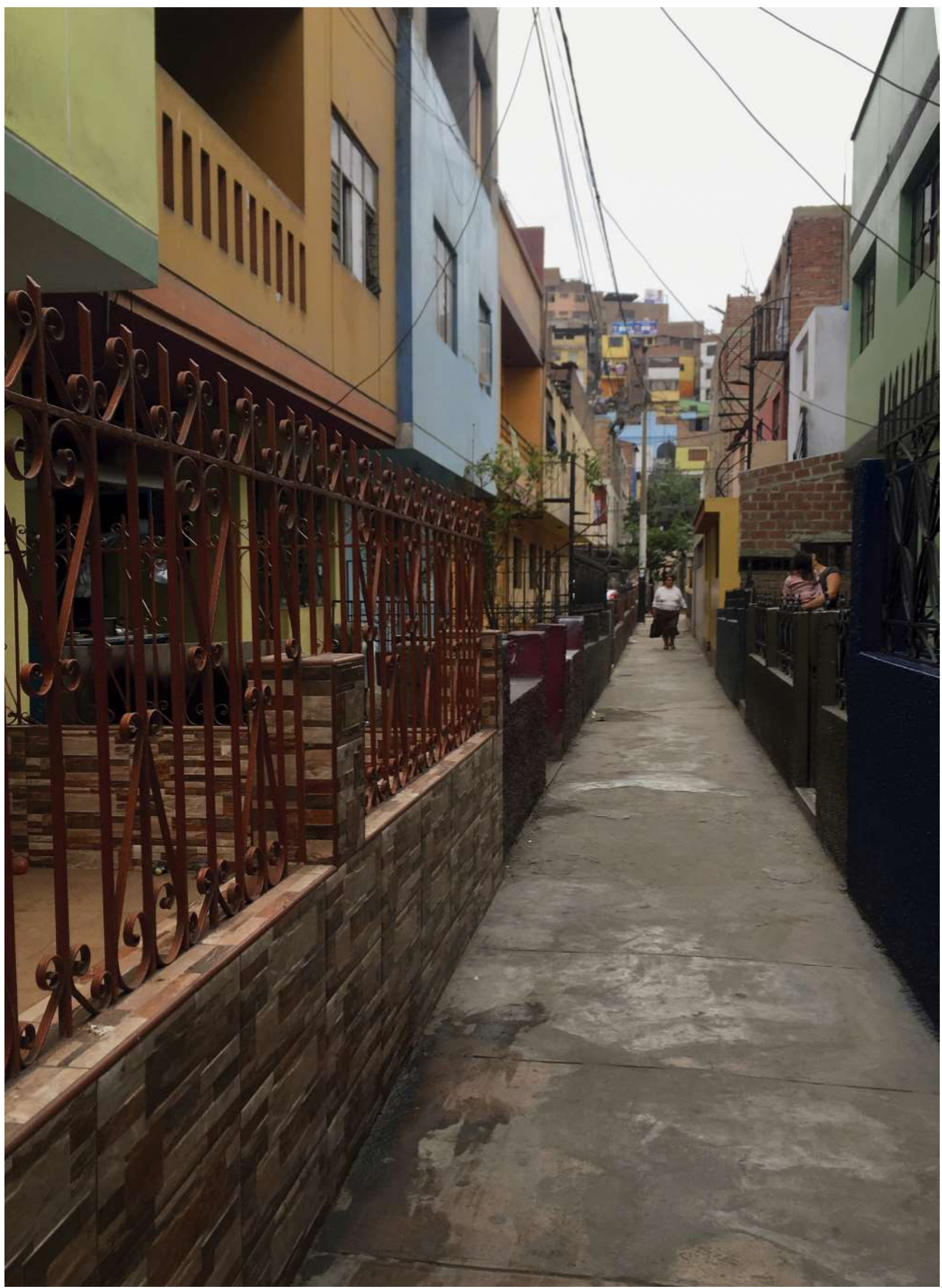

Rímac, 2018. Foto @ Manuel Serpa. De la serie Patrimonio berrinchudo limeño. 